\title{
PROTECTION OF BIODIESEL BASED ON SUNFLOWER OIL FROM OXIDATIVE DEGRADATION BY NATURAL ANTIOXIDANTS
}

\author{
Tahmasebi Enferadi, S. ${ }^{*}$ Rabiei, Z., Vannozzi, G.P. \\ Dipartimento di Scienze Agrarie e ambientali Università degli Studi di Udine, \\ via delle Scienze 208,33100 Udine Italy.
}

Received: September 10, 2005 Accepted: March 25, 2006

\section{SUMMARY}

Biodiesel as an alternative diesel fuel obtained by transesterification of vegetable fats and oils, using alcohol in the presence of a catalyst, has some advantages such as reduced emissions of unburned hydrocarbons, carbon monoxide, sulfates, polycyclic aromatic hydrocarbons, and particular matter, but its drawback, of being more prone to oxidation than petroleum-based diesel fuel, can cause the fuel to become acidic (cause fuel system corrosion) and to form insoluble gums and sediments and consequently increase its viscosity. In this study, in order to increase the stability of biodiesel based on high oleic acid sunflower oil against oxidation process during the storage and distribution, different percents $[0.01 \%, 0.02 \%, 0.05 \%, 0.1 \%$, and $0.2 \%(\mathrm{w} / \mathrm{v})]$ of maize flour contaminated by mycotoxins, thus useless for human consumption, were added as natural antioxidants. The antioxidant effect increased with concentration up to an optimal level. Above the optimal level, the increase in antioxidant effect with its concentration was relatively small. Oxidative stability of biodiesel was determined using two parallel methods, the Schaal oven storage test (at $70^{\circ} \mathrm{C}$ ) and the Rancimat method (at $110^{\circ} \mathrm{C}$ ). The induction times obtained by the Rancimat method were more similar to the values determined by the oven test. The highest protective effect was observed in samples containing $0.1 \%(\mathrm{w} /$ v) of added antioxidants.

Key words: biodiesel, maize flour, mycotoxin, natural antioxidants, oxidation degradation, sunflower oil

\section{INTRODUCTION}

The process of using either ethanol or methanol, in the presence of a catalyst such as potassium hydroxide, to chemically break an oil or fat molecule into an ester and glycerol, which are then separated from each other, lead to the production of biodiesel. USA made it with methanol and soybean oil and is known as soy

* Phone: (+39) 0432 558665, Fax: (+39) 0432 558603, e-mail: thamasebi@uniud.it 
methyl ester, or methyl soyate, whereas in Europe, it is based on rapeseed oil. Biodiesel from sunflower oil is highly unsaturated and this makes it very prone to oxidation, which can cause the fuel to become acidic, form insoluble gums and sediments that can plug fuel filter (Monyem and Van Gerpen, 2001). The cetane number of biodiesel also increases as the biosiesl oxidized, up to a peroxide value of 80 (Van Gerpen et al., 1997). Higher cetane number means that the fuel autoignites more easily in the engine cylinder. In addition, the hydroperoxides are very unstable and have a tendency to attack elastomers. Although oily raw materials contain high amount of natural antioxidants, which are present as constituents of unsaponifiable matter including tocopherols, phospholipides, carotenoides, chlorophylles, triterpenyl alcohols, and squalene, which inhibit oxidation (Gordon, 1995; Rabiei et al., 2002), and preserve the substrate from rancidity during storage (RuizLopez et al., 1995), they are removed to a great part from raw oil during processing (Malecka, 2002). Tocopherols are known to show high antioxidant activities, which can trap both peroxy radicals and alkyl radicals. The four main tocopherol constituents are termed alpha (5,7,8-trimethyl), beta (5,8-dimethyl), gamma (7,8-dimethyl) and delta (8-methyl) and the antioxidant power of them is in the order of: $\delta>\alpha>\beta>>\gamma$ tocopherol, because $\delta$-tocopherol has no methyl substituents in its ortho-position, resulting in the easiest approach of peroxy radical to prevent oil from oxidation (Ohkatsu et al., 2001). The use of natural antioxidants derived from agricultural products, especially those that are worthless for human consumption, has enough potential for protecting biodiesel against oxidation process. Chemically synthesised compounds such as butylated hydroxyanisole (BHA) and butylated hydroxy toluene (BHT) have been already used as synthetic antioxidants in biodiesel (Mittelbach and Schober, 2003), but tocopherols have been investigated to have stronger effect than BHA and BHT (Heldebrand, 1984; Huang et al., 1994; Chu et al., 1999).

The present study tries to elucidate the effects of various percentages of tocopherol extracted from maize flour $[0.01 \%, 0.02 \%, 0.05 \%, 0.1 \%$, and $0.2 \%(\mathrm{w} / \mathrm{v})]$ on the oxidation of neat biodiesel (100\% biodiesel). The evaluation of oxidative stability of biodiesel was performed by two parallel methods, the Schaal oven storage test (at $70^{\circ} \mathrm{C}$ ) and the Rancimat method (at $110^{\circ} \mathrm{C}$ ).

\section{MATERIALS AND METHODS}

\section{Oil extraction and saponification}

After rigorous monitoring of some household small metallic silos for storage of maize located in northern Italy, we confirmed for one of them being contaminated by mycotoxins, which made maize grains uselessness for human consumption. It was used for oil extraction by micro Soxhlet extraction apparatus in laboratory, fol- 
lowing a pre-treatment in which seeds were purified, rinsed and oven dried at $50^{\circ} \mathrm{C}$ for $24 \mathrm{~h}$.

\section{Biodiesel preparation}

Biodiesel was produced in laboratory, involving the reaction of sunflower high oleic oil, extracted by micro Soxhlet extraction laboratory apparatus from Carnia hybrid sunflower seeds bred by Undine University, with ethanol in the presence of $\mathrm{KOH}$ and the separation of methyl ester (biodiesel) from glycerine by separation funnel.

\section{Tocopherols extraction}

The non-saponifiable matter of the maize oil was isolated by alcoholic potassium hydroxide $(60 \% \mathrm{w} / \mathrm{w})$ saponification and extraction with $150-\mathrm{ml}$ diethyl ether was done by separation funnel. The extract was dried over anhydrous sodium sulphate, filtrated and the solvent removed by rotary evaporation. Non-saponifiable matter developed on thin layer chromatography (TLC) pre-coated by Kieselgel 40, in n-hexane: diethylether $(4: 1)$ and tocopherols zone were identified under UV ray $(245 \mathrm{~nm})$ and then delayered and purified by diethylether (Rabiei, 2002).

\section{Investigation of stabilizing character of tocopherols}

We added $0.01 \%, 0.02 \%, 0.05 \%, 0.1 \%$ and $0.2 \%(\mathrm{w} / \mathrm{v})$ of extracted tocopherol to biodiesel. Primary products of oxidation are detectable on the basis of determination of peroxide value or conjugated fatty acids, polyunsaturated fatty acids exhibiting pairs of unsaturated carbons not separated by at least one saturated carbon (Rabiei, 2002). Secondary products of oxidation are detectable on the basis of some other experiments like gas chromatography of volatile compounds, organoleptic test, anisidin value and carbonil index.

\section{Determination of the oxidative states (peroxide value) by the Schaal oven} storage test

For stability investigation of samples treated with various percentages of tocopherols, we suggest using a rapid, reliable method, such as oven test in which samples are kept at $25-80^{\circ} \mathrm{C}$ (preferably $60^{\circ} \mathrm{C}$ ) in an oven, repeatedly controlling the peroxide value.

The intermediate compounds formed during the oxidation of lipids may react further to form compounds that can cause rancidity. Unsaturated fatty acids in oils are able to react with oxygen and produce peroxide on their double bonds, which is quantified with the iodimetry method. Determination of peroxide value was done according to AOCS Cd 8b - 90. 


\section{Determination of induction time (the Rancimat method)}

Induction time enabled us to identify the starting point of rancidity, accelerated phase and the final point of rancidity (Rabiei, 2002). The induction time is determined according to ISO 6886 by means of the Metrohm Rancimat at $110^{\circ} \mathrm{C}$ (Kolb et al., 2001).

\section{Statistical analysis}

We conducted statistical analyses of triplicate determinations of peroxide values in six biodiesel samples containing various percentages of tocopherol as treatment. ANOVA analyses were performed with Excel software (Microsoft Corp., Redmond, Wa). Differences at $\mathrm{P}<0.1$ were considered as significant.

\section{RESULTS AND DISCUSSION}

Non-saponifiable fractions of sunflower high oleic and maize oil were developed by thin layer chromatography (TLC). The samples were placed on plates pre-coated with Kieselgel 40, developed in n-hexane : diethylether (4:1) and afterwards sprayed with rhodamin 6G (Figure 1). Sterols and 4-methyl sterols, triterpene alcohols, tocopherols and hydrocarbons are the four separated zones. Increased tocopherol level of maize oil samples is clearly shown.

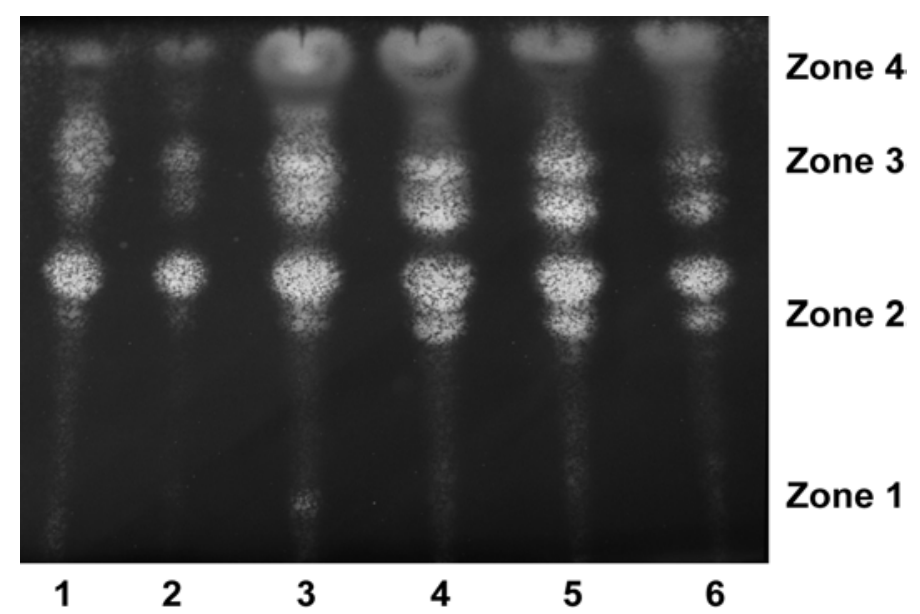

Figure 1: Comparison of non-saponifiable fractions of: 1- sunflower oil (high oleic) 2- rancid sunflower oil (high oleic) 3- 4, 5, 6 oil of maize contaminated by mycotoxins.

The statistical analysis of experimental data revealed that the differences between the treatments were significantly different after 48 hours. Samples 1, 2, 5, and 6 had the same peroxide value, indicating their identical susceptibility to oxidative rancidity. Samples 3 and 4 had lower peroxide values, and therefore higher stability, but they were not significantly different from each other. 
There were significant differences between the samples after 96 hours in the oven at $60^{\circ} \mathrm{C}$. Sample 1 was degraded more than the others, and samples 3 and 4 had lower peroxide value ( 1.05 and $1.1 \mathrm{meq} / \mathrm{kg}$ of oil, respectively).

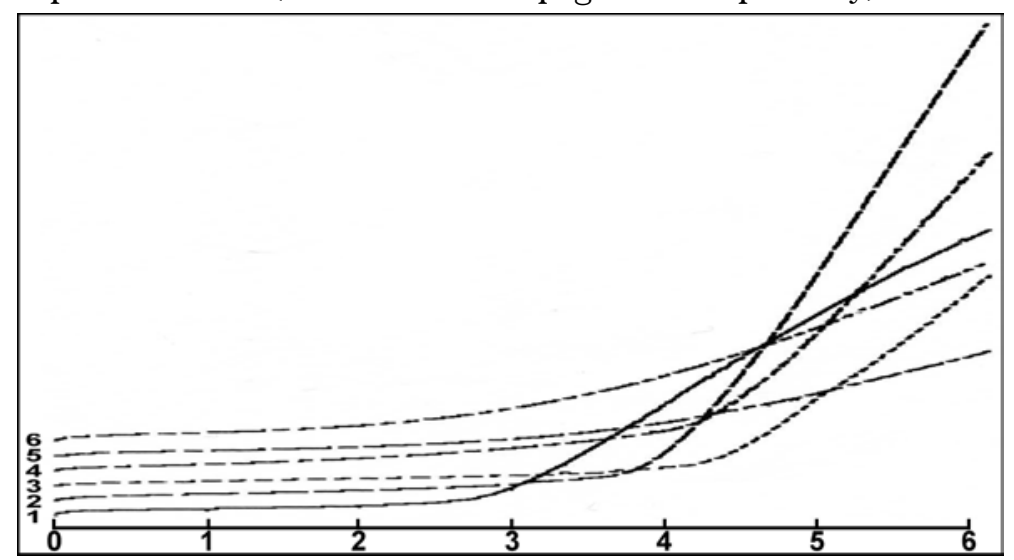

Figure 2: Induction time of samples in the presence and absence of tocopherols (hour), sample $1=$ control, sample 2 = biodiesel $+0.02 \%$ tocopherol, sample $3=$ biodiesel $+0.2 \%$ tocopherol, sample $4=$ biodiesel $+0.1 \%$ tocopherol, sample $5=$ biodiesel $+0.05 \%$ tocopherol, sample $6=$ biodiesel $+0.01 \%$ tocopherol

Still greater significant differences were found in all treatments after 144 hours. Samples 1, 2, 5, and 6 had higher values (each by approximately $3 \mathrm{meq} / \mathrm{kg}$ of oil) and sample 3 , with $0.2 \%$ tocopherol, had a lower value indicating a positive effect of the antioxidant presence in delaying oil oxidation. The differences between the samples were significant after 192 hours. Sample 1 had the highest peroxide value (5.9 $\mathrm{meq} / \mathrm{kg}$ of oil), sample 3 the lowest (3.85 meq $/ \mathrm{kg}$ of oil). The latter was not significantly different from samples 4 and 5 .

Table 1: The variation of peroxide value and induction time of biodiesel containing different percentages of tocopherols

\begin{tabular}{llccccc}
\hline \multirow{2}{*}{ No. Sample } & \multicolumn{4}{c}{$\begin{array}{c}\text { Peroxide value (meq/kg) after incubation time } \\
\text { in oven at } 60^{\circ} \mathrm{C}\end{array}$} & $\begin{array}{c}\text { Induction time } \\
\text { (h) at } 110^{\circ} \mathrm{C}\end{array}$ \\
\cline { 3 - 6 } & & $48 \mathrm{~h}$ & $96 \mathrm{~h}$ & $144 \mathrm{~h}$ & $192 \mathrm{~h}$ & (Rancimat method) \\
\hline 1 & Biodiesel (control) & $1.1 \mathrm{a}$ & $2.35 \mathrm{a}$ & $3.55 \mathrm{a}$ & $5.9 \mathrm{a}$ & 2.93 \\
2 & Biodiesel+0.01\% tocopherol & $1 \mathrm{a}$ & $1.77 \mathrm{ab}$ & $3.5 \mathrm{a}$ & $5.67 \mathrm{ab}$ & 3.84 \\
3 & Biodiesel+0.02\% tocopherol & $1 \mathrm{a}$ & $1.75 \mathrm{ab}$ & $3.5 \mathrm{a}$ & $5.1 \mathrm{~b}$ & 4.0 \\
4 & Biodiesel+0.05\% tocopherol & $1 \mathrm{a}$ & $1.6 \mathrm{ab}$ & $3.15 \mathrm{a}$ & $4.41 \mathrm{c}$ & 4.17 \\
5 & Biodiesel+0.1\% tocopherol & $0.54 \mathrm{~b}$ & $1.1 \mathrm{~b}$ & $2.6 \mathrm{bc}$ & $4.35 \mathrm{c}$ & 4.37 \\
6 & Biodiesel+0.2\% tocopherol & $0.57 \mathrm{~b}$ & $1.05 \mathrm{~b}$ & $2.4 \mathrm{c}$ & $3.85 \mathrm{c}$ & 4.37 \\
\hline
\end{tabular}

Means followed by the same letter are not significantly different at $1 \%$ level as indicated by Duncan's Multiple Range Test.

The regression analysis showed a significant relationship between the decline of peroxide value and doses of tocopherol from grape seed oil. It was revealed that the peroxide values of the treatments containing $0.01 \%$ and $0.02 \%$ of tocopherols 
decreased slightly as compared with the control. It was due to the antioxidant activity conferred to biodiesel by tocopherols.

The progressive increase of peroxide value in the control revealed the deleterious effect of heat on oil stability. The treatments containing $0.1 \%$ and $0.2 \%$ of tocopherols had decreased peroxide values which were significantly different from the control. Significant differences did not occur in all steps of the experiment, as confirmed by the result of the induction time carried out by the Rancimat (Table 1). According to our results, $0.1 \%$ and $0.2 \%$ concentrations showed the same effect on oxidation rate. The results of oven test and induction time overlapped each other.

The overall study suggests that the addition of tocopherols has a positive effect on the shelf life of biodiesel. The higher the concentration of tocopherol, the higher the stability of biodiesel. It was also revealed that $0.1 \%$ and $0.2 \%$ of tocopherol had the same effect on biodiesel stability. Therefore, $0.1 \%$ tocopherol is more economic and probably a threshold dose for stabilizing the biodiesel.

\section{ACKNOWLEDGMENT}

Financial support of Murst (Ministro dell Istruzione, dell Universita, e della Ricerca) is gratefully acknowledged.

\section{REFRENCES}

AOCS, 1997. Official methods of analysis. $16^{\text {th }}$ edition. Oven storage test for accelerated aging of oils.

Chu, Y.H. and H.F. Hsu, 1999. Effects of antioxidants on peanut oil stability. Food Chemistry, 66: 29-34.

Gordon, M.H. and L. Kourimska, 1995. The effects of antioxidants on changes in oils during heating and deep frying. Journal of Sci. Food Agric. 68: 347-353.

Hildebrand, D.H., 1984. Phospholipids plus tocopherol increase soybean oil stability. Journal of American Oil Chemists' Society 61(3): 552-555.

Huang, S.W., E.N. Frankel, J.B. German, 1994. Antioxidants activity of $\alpha$ and $\gamma$-tocopherols in bulk oils and in oil-water emulsions. J. Agric. Food Chem. 42(10): 2108-2114.

Ikwuagwu, O.E., I.C. Ononogbu, O.U. Njoku, 2000. Production of biodiesel using rubber [Hevea brasiliensis (Kunth. Muell.)] seed oil. Industrial Crops and Products No.12: 57-62.

Kohno, Y., Egawa, Y., Itoh, S., Nagaoka, S., Takahashi, M., Mukai, K., 1995. Kinetic study of quenching reaction of singlet oxygen and scavenging reaction of free radical by squalene in n-butanol. Biochem. Biophys Acta 1265(1): 52-56.

Kolb, T., U. Loyall. J. Schafer, 2001. Antioxidants, determination and interpretation of the temperature correlation of oxidative stabilites. Journal of Food Marketing and Technology 21: 1-6.

Malecka, M., 2002. Antioxidants properties of the unsaponifiable matter isolated from tomato seeds, oat grains and wheat germ oil. Food Chemistry 79: 327-330.

Mittelbach, M. and Schober S., 2003. The influence of Antioxidants on the Oxidation Stability of Biodiesel. JAOCS 80(8): 817-823

Monyem, A., Van Gerpen, J.H., 2001. The effect of biodiesel oxidation on engine performance and emissions. Biomass \& Bioenergy 20: 317-325.

Ohkatsu, Y., T. Kajiyama, Y. Arai, 2001. Antioxidant activities of tocopherols. Polymer degradation and stability $72: 303-311$.

Rabiei, Z., 2002. The natural stabilizing factors of grape seed oil on mutton tallow stability. M.Sc. Paper, 6-8: 19 -20. 
Ruiz-Lopez, M.D., Artacho, R., Fernandez Pineda, M.A., Lopwz Garcia de la Serrana, R., Lopez, Martinez, -M.C., 1995. Stability of alfa-tocopherol in virgin olive oil during microwave heating. Lebensm Wiss Technol 28: 644-646.

Van Gerpen, J.H., E.G. Hammond, Y. Liangping, A. Monyem, 1997. Determining the influence of contaminants on biodiesel properties. Society of Automotive Engineers, Paper No. 971658, SAE, Warrendale, PA.

\title{
PROTECCIÓN DE BIODIESEL BASADO EN EL ACEITE DE GIRASOL DE LA DEGRADACIÓN OXIDATIVA POR CAUSA DE LAS INFLUENCIAS DE LOS ANTIOXIDANTES NATURALES
}

\author{
RESUMEN
}

Biodiesel, como el combustible diesel alternativo, obtenido por la transesterificación de las grasas y aceites vegetales, utilizando el alcohol en la presencia de catalizador, tiene algunas ventajas, como la disminuida descarga de los hidratos de carburo no combustidos, monóxido de carbón, compuestos de azufre, carbohidratos policíclicos aromáticos, y otras materias, pero también tiene una desventaja, que es de ser más sensible a oxidación que el combustible diesel, originado del petróleo. La oxidación influye en el incremento de acidez del combustible (causa la corrosión en el sistema de combustible) y forma un sedimento insoluble, con lo que se incrementa la viscosidad del mismo. Para incrementar la estabilidad del biodiesel originado del girasol de alto contenido oleico en cuanto a la oxidación, durante el almacenamiento y transporte, en esta investigación íbamos añadiendo diferentes porcentajes [0,01\%, $0,02 \%, 0,05 \%, 0,1 \%$, y $0,2 \%$ ] de harina de maíz, infectado por micotoxinas, y por lo tanto inútil para la alimentación humana, como antioxidante natural. La influencia antioxidante iba incrementándose con la concentración hasta un óptimo nivel. Por encima de ese nivel, la influencia antioxidante iba incrementándose muy poco. La estabilidad oxidativa del biodiesel, es determinada mediante la utilización paralela de dos métodos, la prueba de Schaal en el horno (a 70ucción, obtenidos por el Método de Rancimat, tenían los valores semejantes a los obtenidos por la prueba en horno. La mayor influencia protectiva fue reportada en las muestras que contenían $0.1 \%$ de antioxidantes adicionales.

\section{PRÉSERVER LE BIODIESEL FAIT À PARTIR D'HUILE DE TOURNESOL D'UNE DÉGRADATION OXYDATIVE DUE À DES ANTIOXYDANTS NATURELS}

\author{
RÉSUMÉ
}

Le biodiesel en tant que combustible diesel alternatif obtenu par transestérification de gras et d'huiles végétaux avec utilisation d'alcool en présence d'un catalyseur a quelques avantages comme par exemple des émissions réduites d'hydrocarbures non brûlés, de carbone monoxyde, de sulfates, d'hydrocarbures aromatiques polycycliques et autres matières, mais son inconvénient est qu'il est plus sujet à l'oxydation que le combustible diesel à base de pétrole et qu'il peut rendre le combustible acide (causer la corrosion du système combustible) et former une couche insoluble et ainsi augmenter sa 
viscosité. Dans le but d'augmenter la stabilité du biodiesel à base de tournesol à haute teneur d'acide oléique contre le processus d'oxydation au cours de l'entreposage et de la distribution, différents pourcentages $[0,01 \%, 0,02 \%$, $0,05 \%, 0,1 \%$ et $0,2 \%(\mathrm{w} / \mathrm{v})]$ de farine de maïs contaminée par des mycotoxines et donc impropre à la consommation humaine, ont été ajoutés comme antioxydants naturels. Avec la concentration, l'effet antioxydant a augmenté jusqu'à un niveau optimal. Au-dessus du niveau optimal, l'effet antioxydant a très peu augmenté. La stabilité oxydative du biodiesel a été déterminée à l'aide de deux méthodes parallèles, le test Schall au four $(a ̀) 70^{\circ} \mathrm{C}$ ) et la méthode Rancimat (à $\left.110^{\circ} \mathrm{C}\right)$.

Les temps d'induction obtenus par la méthode Rancimat ont été semblables aux valeurs obtenues par le test au four. Le plus grand effet de protection a été observé chez les échantillons contenant $0,1 \%$ (w/v) d'antioxydants ajoutés. 